\title{
The Main Directions of International Educational Integration: Potential Benefits and Risks of Reforming Professional Education
}

\author{
Roman V. Kupriyanov ${ }^{1}$, Renat N. Zaripov ${ }^{1}$, Nailya S. Valeyeva ${ }^{1}$, Elvira R. Valeyeva ${ }^{1}$, Irina R. Zaripova ${ }^{1}$ \& \\ Marina I. Nadeyeva ${ }^{1}$ \\ ${ }^{1}$ Kazan National Research Technological University, Kazan, Russia \\ Correspondence: Roman V. Kupriyanov, Kazan National Research Technological University, K. Marks Street 68, \\ Kazan, 420015, Russia. E-mail: elm.khair@list.ru
}

Received: January 17, 2015 Accepted: January 29, 2015 Online Published: February 26, 2015

doi:10.5539/res.v7n3p305 URL: http://dx.doi.org/10.5539/res.v7n3p305

\begin{abstract}
The purpose of this article is to reveal the influence of the main areas of international educational integration on the processes of reforming the national professional education. The paper presents the main areas of the international educational integration at the level of statutory regulation, at the level of the goals and mission of higher professional education, at the level of organizational-structural changes, at the level of quality assurance of professional education, at the training content and management levels. The authors also proved the competitive advantages and disadvantages of the Russian market of educational services, the benefits and risks of reforming professional education under the conditions of international educational integration, economic and social effects of teaching foreign students in Russian universities. The article contents may be used by departments of international cooperation of professional educational institutions in the development of mechanisms for integrating Russian professional schools into a single educational space, as well as in the development of courses and teaching and learning aids for university heads on the issue of reforming professional education in the context of the Bologna and Copenhagen processes.
\end{abstract}

Keywords: international educational integration, benefits and risks, reforming, professional education

\section{Introduction}

The need to study the integration processes in the professional education system is dictated by the fact that they reflect the general processes of international integration in the social sphere, have basic development trends and requirements for education in a changing world. It is also due to the expansion of economic and humanitarian cooperation in the context of current issues of intercultural interaction in the globalizing world.

Globalization, according to its nature, serves the harmonization of the world, of human relations, interaction of political systems, the mutual enrichment of national cultures, but in its distorted form can facilitate their unification, simplification and standardization. It should also be taken into consideration that the world processes involve countries with different cultural attitudes and at different stages of development. It is clear that in such circumstances it is difficult to create conditions for equality of opportunities in education.

Since Russia's accession to the Bologna Process in September 2003, as important factors to improve the work of universities, common European reference points of development have come to the fore. This makes it necessary to reconsider the organizational, structural and other elements of higher education. Still, the existing differences between the education systems, traditions, inertia of isolation-constrain the rapprochement. Although some Russian universities have been developing international relations for quite a long time with universities in Europe, many problems still persist: recognition of diplomas is complicated by weak comparability of the content and structure of training; our graduates have to undergo additional training at a University of another country, in order to continue education there or get employed (Mayburov, 2003; Kostyushina, 2003; Fedotov, 2004; Kuproyanov \& Kozlova, 2013; Khairullina et al., 2015).

In the countries of the European Union, the increase in number of foreign students is one of the most important priorities of the state policy. In an effort to strengthen its competitive positions, the European Union among its priorities set the task of creating a common European Educational Space (EES), along with a common European Research Area (ERA) 1. 
The experience of economically developed countries shows that one of the underlying factors promoting the speeding up of their economies in 60-70 years was the implementation of national educational programs that ensured development of human opportunities and training of workers able to learn the latest techniques and technologies.

Meanwhile, as noted in the "Concept of long-term socio-economic development of the Russian Federation until 2020 ", "to date, Tertiary School in many respects has lost an innovative, research component. Only 16\% of teachers are doing research, less than $10 \%$ of universities have a research budget exceeding 50 thousand rubles a year per teacher. The Russian universities are virtually not present in the international university rankings." (Ivanov, 2006; Pelikhov, 2009; Sadlak, 2007; Karimov, 2014; Sakhieva et al., 2015).

The main purpose of International Cooperation in Education - is to increase quality and strengthen educational and scientific-technical capacity of Russia, its competitiveness in the world market of research and educational services and, as a consequence, to ensure an intensive and effective transition of the Russian economy to an innovative way of development while preserving the traditions and prestige of the national education system.

\section{Methodological Framework}

The analysis of the general Bologna documents showed that the formation of the European educational space began long before the signing of the Bologna Declaration. So, in 1988, in the University of Bologna at the Rectors' Conference of European universities there was adopted the Universal Charter of Universities (Magna Charta Universitatum), which emphasized a special role of universities as centers of culture, knowledge and research that can provide the necessary dynamics of creating a European educational space. An important event on the way of further convergence of national education systems of the European Region was the adoption of Convention in 1997 in Lisbon "On the Recognition of Qualifications, concerning Higher Education in the European Region." Then, in 1998 in Paris, there followed the official signing of a joint declaration by Ministers of Great Britain, Germany, Italy and France on harmonization of the architecture of modern higher education system (Sorbonne Declaration), stimulating the formation of the European Higher Education Area, with reliance on the basic provisions of the Lisbon Convention. Thus, the stage was set for the adoption of the Bologna Declaration, which in 1999, in Bologna, was signed by the heads of educational systems of 29 countries in Europe. This declaration contains six basic principles for the formation of the European system of higher education: the introduction of a two-level higher education; the introduction of a system of credits (ECTS); quality assurance; mobility of students and teachers promotion; assistance for students' employment and improvement of European education competitiveness; formation of a European approach to the development of higher education.

\section{Literature Review}

It is well known that the Russian system, and before that, the Soviet system of education had always been distinguished by a high scientific and fundamental, active participation in international processes, including the field of scientific comparative studies. A great contribution to the study of foreign education systems was made by such leading Russian scientists as Brazhnik (2004), Wolfson (2002), Dzhurinskiy (1993), Ivanov (2002), Kovalenko (1997), Malkova (1983, 1998, 1999), Nikandrov (1978, 1995), Frumov (1960), and others.

Certain aspects of the status and development of education systems of Western European countries are covered in the works of Gurye (1993), Dobrynina (1996), Kremnyeva (1999), Kurdyumova (2002), Pisareva (1997), Smirnova (1988), Fedorova (2007). Development of problems connected with the use of the positive experience of foreign professional education systems is conducted by scientists of the Institute of Pedagogy and Psychology of Professional Education of the Russian Academy of Education (Tregoubova, 2011; Masalimova, 2006; Sakhieva, 2008; Sagitova, 2010, etc.).

Various aspects of the international activities of Russian universities have been considered in the works of Russian and foreign scholars. Thus, the general issues of international cooperation between universities were studied by Kinelev (1999), Kurila (2003), Borisova (2004, 2012), Volkova (2001), Zverev (2010), Knyazev (2003); the specifics of the integration of Russian higher education into the Common European educational space were analyzed by Baeva (2005), Pavlenko (2006), Peregudova (2004), Onoka (2004) and Larionova (2004); issues of globalization of higher education were studied by Bauman (2004), Belov (2005), Beerkens (2003, 2004), Beck (1999), Bhagwati (2005), Branch (1999), etc.

The coverage of the implementation of Bologna individual tasks abroad is presented in domestic works by Galagan (2005), Vorobyeva (2006), Kurdyumova (2002), Troshina (2005), Sazonova (2006). The development of universities in Western Europe is paid considerable attention in the writings of such researchers, as Malkova 
(1999) and Truevtseva (1978). Historical aspects of the formation and distinguishing features of the French higher education are revealed in the books by Golovko (1978), Dzhurinskiy (2004) and Uvarova (1984), ceratin aspects of reforming higher education in France were considered in Grigoryeva's (2006), Martynenko's (2009), Negrebetskaya's (2003), and Orekhova's (2004) dissertations.

\section{Results}

\subsection{The Directions of the International Educational Integration}

We have carried out systematization of the main directions of the international educational integration in the context of the Bologna and Copenhagen processes at the following levels: at the level of statutory regulation, at the level of goals and mission of higher professional education, at the level of institutional organizational-structural changes, at the level of quality assurance of professional education, at the level of professional training content, at the management level:

\subsubsection{Statutory Regulation Level}

At the regulatory level there happen synchronous changes in statutory acts, the definition of the legal status of joint international educational programs, including programs of double and joint degrees; standardization (Russian - is focused on the state regulation of the education content, American - is characterized by defining the objectives and by strict accountability of schools to the State, by states independently establishing the standards, European - being determined by a combination of standardization of educational content on the part of the state and autonomy of regions and schools in establishing the system of requirements, strict accountability of schools and regions).

\subsubsection{Institutional Level}

At this level the development and implementation of transnational programs and projects are enabled in the field of education and research activities in the education system; improvement of the structure and volume of personnel training on the basis of the transition to three-level system of training, including preliminary unification of areas and specializations; participation in the joint development of a generalized framework of qualifications for the Common European Higher Education Area; making the decision on the existence of areas of training according to the specializations in the new list.

\subsubsection{Functional Goals Level}

At the level of the goals and mission of higher professional education there are highlighted global objectives - assistance through the deepening of cooperation in the field of education to the overall socio-economic progress and sustainable development of the world community, to easing the pressure of global issues and promoting mutual understanding between the nations; intersystem (educational) - the union of the capacity of national education systems to solve problems beyond the capacity of individual countries and related to the elimination of illiteracy of all types, inequalities in access opportunities to quality education using the latest technologies, education based on universal values of a person, who is aware of not only the national and cultural identity, but also perceiving the world in all its integrity and interdependence, understanding their personal responsibility for its predestination and being ready to act constructively for its preservation and development.

\subsubsection{The Level of Quality Assurance of Professional Education}

This level is characterized by the development of international cooperation in the field of quality control with a view to developing comparable criteria and methodologies, and the credit system.

\subsubsection{The Content Level}

At the level of the content of professional education the selection and structuring of educational content are carried out, as well as fundamentalization and humanitarization, integration and internationalization, the modular structure of educational content.

\subsubsection{Management level}

This level implies the existence of public authorities; monitoring of the labor market and educational services, the establishment and maintenance of mechanisms and organizational structures of interaction with employers; use of modern, technological tools in university management; strategy of a university for the organization of advanced training in relevant areas of expertise.

One of the main areas of international educational integration is the introduction of a multi-level professional education. In this regard, during the experimental work we found that most of the difficulties arise from the 
recognition of a bachelor's degree. Consequently, there is a need for additional training in enterprises because of their unavailability to perform certain tasks for the enterprise.

\subsection{Benefits and Risks of Reforming Professional Education in the Conditions of International Educational Integration}

Based on the analysis of the literature, we studied the views of experts on the reforming of professional education in the conditions of international educational integration, which are presented in the table.

Table 1. The main controversies between supporters and opponents of reforming professional education

\begin{tabular}{|c|c|c|c|}
\hline Factors of change & $\begin{array}{l}\text { Positive } \\
\text { tendencies }\end{array}$ & $\begin{array}{l}\text { Negative } \\
\text { tendencies }\end{array}$ & Results \\
\hline 1. Globalization & $\begin{array}{l}\text { Democratization; blurring } \\
\text { of boundaries; increasing of } \\
\text { social and academic } \\
\text { mobility }\end{array}$ & $\begin{array}{l}\text { Polarization of the } \\
\text { Western world from the rest } \\
\text { of mankind; "brain drain" } \\
\text { from the less developed and } \\
\text { moderately developed } \\
\text { countries to the Western } \\
\text { world countries }\end{array}$ & $\begin{array}{l}\text { International division of } \\
\text { labor (including the } \\
\text { transnational and regional } \\
\text { level) }\end{array}$ \\
\hline $\begin{array}{l}\text { 2. Joining the Bologna } \\
\text { process (as one of the } \\
\text { manifestations } \\
\text { globalization) }\end{array}$ & $\begin{array}{l}\text { The emergence of the } \\
\text { second pole }\end{array}$ & $\begin{array}{l}\text { Creating tension between } \\
\text { the poles }\end{array}$ & $\begin{array}{l}\text { Integration into the } \\
\text { European Social and } \\
\text { Economic Community }\end{array}$ \\
\hline $\begin{array}{l}\text { 3. Unification } \\
\text { standardization } \\
\text { education }\end{array}$ & $\begin{array}{l}\text { Recognition of Russian } \\
\text { diplomas; intensification of } \\
\text { education; training time } \\
\text { reduction; increase in the } \\
\text { average population stratum } \\
\text { as a basis for sustainable } \\
\text { development of the nation }\end{array}$ & $\begin{array}{l}\text { Decrease in standards of } \\
\text { Russian education to the } \\
\text { level of pan-European; } \\
\text { social inequality increase }\end{array}$ & $\begin{array}{l}\text { Democratization; social and } \\
\text { academic mobility increase }\end{array}$ \\
\hline 4. Integration & $\begin{array}{l}\text { Cooperation of nations and } \\
\text { development of their } \\
\text { leaders }\end{array}$ & $\begin{array}{l}\text { Loss of national features of } \\
\text { educational systems }\end{array}$ & $\begin{array}{l}\text { The creation of a Common } \\
\text { European educational space }\end{array}$ \\
\hline 5. Informatization & $\begin{array}{l}\text { Reduced time } \\
\text { knowledge updates }\end{array}$ & $\begin{array}{l}\text { The distortion of the } \\
\text { humanistic values of } \\
\text { education, its } \\
\text { pragmatization; a new } \\
\text { threat to national security }\end{array}$ & $\begin{array}{l}\text { Simplification and the cost } \\
\text { reduction of consciousness } \\
\text { formation technology }\end{array}$ \\
\hline 6. Convergence & $\begin{array}{l}\text { Convergence } \\
\text { interpenetration and } \\
\text { educational and social } \\
\text { systems }\end{array}$ & $\begin{array}{l}\text { Blurring of national and } \\
\text { ethnic identities }\end{array}$ & $\begin{array}{l}\text { Greater coherence of } \\
\text { society and decrease in the } \\
\text { potential for conflicts }\end{array}$ \\
\hline
\end{tabular}

Taking into account positive and negative sides of reforming professional education, revealed by experts, we have supplemented and substantiated a number of possible educational, social and economic benefits and risks of this process in the conditions of international educational integration.

\subsubsection{Benefits}

- Pedagogical benefits: recognition of Russian universities diplomas by employers in other countries; attraction of highly qualified teaching staff; transition to a modular system for evaluating knowledge;

- Social benefits: engaging students with high research potential; ability to support contacts with a variety of international communities; social and academic mobility increase; opportunity to continue education at any university; intensification of professions' geographical mobility; 
- Economic benefits: financial attractiveness of Russian education to foreign nationals; budget savings by reducing the period of study of the total number of students for one year; replenishment of labor shortages in own country through the consolidation of foreign students after completing their education.

\subsubsection{Possible Risks}

- Pedagogical risks: reduction of the fundamental component, which affects the quality of training future specialists; loss of highly qualified teaching staff of the graduate chairs-specialists in specific sectors of professional knowledge in connection with the reduction of the periods of study; loss of continuity of scientific schools due to a rapid aging of faculty members in universities;

- Social risks: emergence of bachelors' problems with employment; loss of the status of the Russian primary and secondary professional education; low level of competitiveness of professionals as a result of reduction of terms of training;

- Economic risks: increase in the cost of individual training of Masters because of the low number of the best graduates of a bachelor degree capable to study a Master's.

\subsubsection{Economic and Social Effects of Teaching Foreign Students}

Expert study of the international market of educational services of higher professional education in the conditions of globalization and internationalization also made it possible to determine the economic and social effects of teaching foreign students:

- Economic: increase in revenue by providing educational services to international students; optimization of the costs for training the national personnel; additional revenue from the residence of foreign students in the country; replenishment of labor shortages in our own country through the consolidation of foreign students upon completion of their education;

- Social: attracting students with high research potential; the ability to support contacts with a variety of international communities and special interest groups; reproduction of value system in foreign students, allowing to work in the Russian market; increase of geographical mobility of professions.

Analysis of the expert survey of student preferences led to the conclusion that above all, in the international market business education is valued ( $25 \%$ of it is acquired by students). Those are the specializations related to economics, management, marketing, and business information systems. Almost $20 \%$ of students are studying technical and engineering sciences, the most popular of them - are information technologies. Approximately the same numbers of students choose natural sciences. The list of occupations is completed by social specializations (7-8\%), art (5-6\%), and medicine (5-4\%).

Consequently, the Russian market of educational services today must teach in fields that require basic training (science-intensive specializations, where it is important to have complete and systematic understanding of the subject of studying - mathematics, physics, biology) and to train specialists in such mass professions as sociologists, managers, doctors, but at the same time providing a turnover due to low prices in comparison with other countries.

\section{Discussions}

In connection with the reforming of professional education in the conditions of international educational integration of Russia there is a chance to increase the competitiveness of the education, however, this will be difficult owing to a number of circumstances:

The global market of education and labor is represented by strong competitors, at the same time, the Russian higher education has a number of competitive advantages, including: the experience of creating the world's best technical education; experience in teaching foreign students; fundamental nature of Russian education; low cost of educational services.

Potential sphere of activity in the field of educational services export can also be the neighboring countries, Russian-speaking immigrants from Russia, who in the future are going to connect their business with the Russian economy. A real opportunity to attract this category of students is to use distance learning technologies, but the technical capabilities of Russian universities can become a restriction for teaching students through the Internet.

\section{Conclusion}

Thus, the presented in the article main directions of international educational integration at the level of statutory regulation, at the level of the goals and mission of higher professional education, at the level of organizational-structural changes, at the level of quality assurance of professional education, at the content and 
management levels, as well as the expert study of the international market of educational services of higher professional education in the conditions of globalization and internationalization, made it possible to identify and substantiate the competitive advantages and disadvantages of the Russian market of educational services, the benefits and risks of reforming professional education in the conditions of international educational integration, economic and social effects of teaching foreign students in Russian universities. Considering the positive and negative sides of reforming professional education, revealed by experts, we have supplemented and substantiated a number of possible educational, social and economic benefits and risks of this process in the conditions of the international educational integration.

To represent the country's interests in the world education market, and its successful development, a balanced and sound public policy is required, which is based on knowledge of the laws and requirements of the global market, on combined efforts of public and private organizations being able to advance this education.

\section{References}

Baeva, E. A. (2005). Reform of higher education in Russia in the context of the Bologna process (p. 195). Kirov: VSEI.

Bauman, Z. (2004). Globalization: Implications for the individual and society (pp. 112-145). Moscow.

Beck, U. (1999). What Is Globalization? (pp. 9-45).Cambridge: Policy Press.

Beerkens, E. (2003). Globalization and Higher Education Research. Studies in International Education, 2, 141. http://dx.doi.org/10.1177/1028315303007002002

Beerkens, E. (2004). Global Opportunities and Institutional Embeddedness. Higher Education Consortia in Europe and Southeast Asia, 354.

Belov, V. A. (2005). Globalization and geopolitical issues of Russian education text. Legal education and science, $1,28-30$.

Bhagwati, D. (2005). In Defense of Globalization (p. 406). Moscow.

Borisova, I. V. (2004). Semantics of egocentric categories: LIEBE, HASS and their actualization in German language consciousness (p. 371). Irkutsk.

Borisova, I. V. (2012). Pedagogical concepts and relationships between them. Omsk Scientific Bulletin, 109, 187-190.

Branch, M., Grace, A., \& Coleman, T. (1999). A Optimization toolbox for use with Matlab. User's Guide: Version 2. The MathWorks.

Brazhnik, E. I. (2004). School education in overseas educational research (pp. 82-89). St. Petersburg.

Dobrynina, M. A. (2006). Bologna Declaration as a factor of European educational space. Pedagogy, 9, 103-108.

Dzhurinskiy, A. N. (2004). Internationalization of higher education in the modern world. Pedagogy, 3, 83-92.

Dzhurinskny, A. N. (1993). International School: Current status and development trends (p. 190). Moscow: Education.

Fedorova, E. E. (2007). Problems of adaptation of students for professional careers in university (pp. 71-75). Pedagogy: scientific and theoretical journal.

Fedotov, H. N. (2004). Globalization in Education: Bologna process text. Philosophy Islands, 2, 21-29.

Frumov, S. A. (1960). French school and fight for its democratization (p. 197). Moscow.

Galagan, A. I. (2005). The Bologna Process and Engineering Education. Analyzes on the main directions of development of higher education, 9, 1-51.

Galagan, A. I., \& Pryanishnikova, O. D. (2005). Bologna process and engineering education. Research Institute for Higher Education. Analyzes on the main directions of development of higher education, 9, 1-51.

Golovko, S. A. (1978). Reform of university education in France in the late 60's and early 70-ies of XX century (p. 190). Minsk.

Grigorieva, E. V. (2006). Competence approach in today's higher professional education (p. 169). Moscow.

Gurye, L. I. (1993). Initial vocational education in France (problems and trends) (p. 343). Kazan.

Ivanov, D. I. (2002). Development of international cooperation of Russian universities (p. 182). Kazan.

Ivanov, V. I. (2006). Bologna process and Russian higher education text. Pedagogy, 1, 97-106. 
Karimov, A. R. (2014). Virtue Epistemology and Psychology of Education. Life Science Journal, 11(9), 45-50.

Khairullina, E. R., Valeyev, A. S., Valeyeva, G. K., Valeyeva, N. S., Leifa, A. V., Burdukovskaya, E. A., \& Shaidullina, A. R. (2015). Features of the Programs Applied Bachelor Degree in Secondary and Higher Vocational Education. Asian Social Science, 11(3), 213-217.

Kinelev, V. G. (1999). Education and XXI century: Information and communication technology (pp. 88-93). Moscow: Nauka.

Knyazev, E. A., \& Vashurina, E. V. (2003). Training university administrators: Foreign experience. In Strategic management and institutional research in higher education (pp. 65-70). Kazan: FiztehPress.

Kostyushina, Y. I. (2003). International cooperation as a factor of sustainable development of the national high school (p. 147). Ryazan.

Kovalenko, N. (1997). People pedagogy code of moral education. School, 3, 20-25.

Kremneva, T. L. (1999). Training of social workers in the UK (p. 179). Moscow.

Kupriyanov, R., \& Kozlova, I. (2013). Developing double degree bilingual master's program "social work in industry” (pp. 633-635). 2013 International Conference on Interactive Collaborative Learning, ICL.

Kurdyumova, I. M. (2002). Training management education abroad. Pedagogy, 3, 98-105.

Kurila, I. I. (2003). Bulletin of Volgograd State University. University education, 6, 73-80.

Larionova, M. V. (2004). Formation of European educational space text: Challenges for higher education in Russia. Education Matters, 4, 14-21.

Malkova, Z. A. (1983). School and pedagogy abroad (p. 192). Moscow: Education.

Malkova, Z. A. (1998). The historical lesson of the American school (p. 4). Pedagogika.

Malkova, Z. A. (1999). Broken educational area. Pedagogika, 5, 103-110.

Martynenko, L. G. (2009). Organization of the monitoring and evaluation of students in universities in Russia and France (p. 22). St. Petersburg.

Masalimova, A. R. (2006). Foreign experience of integration of research, teaching and practice of students of higher technical school. Kazan: Pedagogical journal, 5, 54-61.

Masalimova, A. R. (2006). Prospects for the use of foreign experience of training engineers in the Russian system of vocational education. Proceedings of the higher educational institutions, 5-6, 85-92.

Mayburov, I. (2003). Higher education in developed countries. Higher education in Russia, 2, 132-144.

Negrebetskaya, N. V. (2003). The main trends in the development of higher pedagogical education of Western Europe in the late 20th century (p. 150). Belgorod.

Nikandrov, N. D. (1978). Modern School of capitalist countries (p. 204). Moscow: Higher School.

Nikandrov, N. D. (1995). Russian education on the background of the economy, social policy and culture. Masters, 6, 1.

Onokoy, L. S. (2004). Russia's integration into the European system of education. Sociological issued, 2, 80-85.

Orekhova, E. Y. (2004). Education in France: Tradition and reform (p. 352). Tula.

Pavlenko, E. V. (2006). Integration of Russian higher education in the European educational space text (p. 161). Rostov-ND.

Pelikhov, N. V. (2009). Targets university development. Space economy, 3, 297-299.

Peregudova, Y. M. (2004). Problems of development of Russian higher education in the context of the Bologna process text (pp. 128-132). Moscow.

Pisareva, L. I., Alferov, Y. S., \& Kurdyumova, I. M. (1997). Estimate and certification of personnel education abroad (p. 145). Moscow.

Sadlak, J. (2007). Bologna process: Regional response to global challenges. Higher education today, 10, 16-20.

Sagitova, R. R. (2010). Genesis essence of the concept of self-education in the history of domestic and foreign pedagogy. Vestnik Buryat State University, 1, 35-41.

Sakhieva, R. G., Khairullina, E. R., Khisamiyeva, L. G., Valeyeva, N. S., Masalimova, A. R., \& Zakirova, V. G. (2015). Designing a Structure of the Modular Competence-Based Curriculum and Technologies for Its 
Implementation into Higher Vocational Institutions. Asian Social Science, 11(2), 246-251.

Sakhieva, R. G., Tregubova, T. M., Masalimova, A. R., Belyakin, A. M., Fakhrutdinova, A. V., \& Tazutdinova, E. H. (2008). Academic mobility of students in higher education: National and international experience of it's formation (p. 131). Kazan: Publishing House "Fatherland".

Sazonova, B. A. (2006). Topical issues of modernization of Russian higher education (p. 184). Moscow.

Smirnova, E. L. (1988). Ways of formation of arbitrary behavior. Preschool education, 10, 51-54.

Tregubova, T. M. (2011). Theory and practice of social work with young students in vocational education institutions in the USA (p. 417). Kazan.

Troshina, E. V. (2005). Formation of innovative control systems research and development in science and technology organizations (p. 190). Eagle.

Truevtseva, S. S. (1978). Crisis of the French University and its reflection in bourgeois sociology of education (p. 209). Leningrad.

Uvarova, P. Y. (1984). Characteristic features of university culture. In From the history of universities in Europe XIII-XV century (pp. 5-28). Voronezh.

Volkova, L. P., Getmanova, G. I., Antakanova, L. B., \& Zornikov, I. N. (2001). International cooperation in the field of higher education (p. 18). Voronezh: University Press.

Vorobyev, N. E., \& Grachev, V. G. (2006). Current status and trends of development of teacher education in Western Europe (p. 144). Volgograd.

Wolfson, B. L. (2002). Global educational environment at the turn of XX and XXI centuries. Pedagogy, 10, 3-15.

Zverev, N. I. (2010). Software targets of Russian export of educational services. National interests: Priorities and security, 17(74), 6-14.

\section{Copyrights}

Copyright for this article is retained by the author(s), with first publication rights granted to the journal. This is an open-access article distributed under the terms and conditions of the Creative Commons Attribution license (http://creativecommons.org/licenses/by/3.0/). 